\title{
Impact of three-spined stickleback Gasterosteus aculeatus on zooplankton and chl $a$ in shallow, eutrophic, brackish lakes
}

\author{
Tue Stenholm Jakobsen ${ }^{1, *}$, Pia Borch Hansen ${ }^{1}$, Erik Jeppesen ${ }^{1,2}$, Peter Grønkjær ${ }^{3}$, \\ Martin Søndergaard ${ }^{1}$ \\ ${ }^{1}$ Department of Freshwater Ecology, National Environmental Research Institute, Vejlsøvej 25, PO Box 314, \\ 8600 Silkeborg, Denmark \\ ${ }^{2}$ Department of Botanical Ecology, Biological Institute, Aarhus University, Nordlandsvej 68, 8240 Risskov, Denmark \\ ${ }^{3}$ Department of Marine Ecology, Biological Institute, Aarhus University, Finlandsgade 14, 8200 Århus N, Denmark
}

\begin{abstract}
The 3-spined stickleback Gasterosteus aculeatus often dominates fish communities in eutrophic, brackish, north-temperate lakes where it is thought to contribute significantly to the low zooplankton biomass and low grazing pressure on phytoplankton. To elucidate its effect on zooplankton community structure and phytoplankton biomass (chl a), we conducted a 5.5 mo enclosure experiment with sticklebacks at different densities in high nutrient concentrations and a salinity of 2 psu. Increasing fish density ( 0 to 10.2 sticklebacks $\mathrm{m}^{-2}$ ) led to substantial changes in the zooplankton community structure, an increase in phytoplankton chl $a$, and a reduction in water clarity. At densities below 4 to 6 sticklebacks $\mathrm{m}^{-2}$, large-bodied cladocerans dominated the zooplankton biomass, the zooplankton:phytoplankton biomass ratio was high $(>1)$, and chl a was accordingly low $\left(<20 \mu \mathrm{g} \mathrm{l}^{-1}\right)$. At higher stickleback densities, large cladocerans disappeared and the abundance of small cladocerans was low. Instead, cyclopoid copepods and rotifers dominated, the zooplankton:phytoplankton biomass ratio was well below 0.5 , and chl a exceeded $200 \mathrm{~g} \mathrm{l}^{-1}$ in late summer. The fish density level for a shift from a clear to a turbid state is low compared to the densities observed in several eutrophic, brackish lagoons. We conclude that fish have a strong impact on water clarity in shallow, eutrophic, brackish lakes with low salinity, which may explain the usually low zooplankton:phytoplankton biomass ratio and the turbid state of such aquatic environments. However, our results also indicate that once the density level declines to below 4 to 6 sticklebacks $\mathrm{m}^{-2}$, a shift to a clear state is likely to occur.
\end{abstract}

KEY WORDS: Sticklebacks · Predation · Top-down control $\cdot$ Saline $\cdot$ Brackish lakes Resale or republication not permitted without written consent of the publisher

\section{INTRODUCTION}

In freshwater lakes, fish predation strongly influences zooplankton community structure and abundance (Hrbácek et al. 1961, Brooks \& Dodson 1965). Particularly in eutrophic lakes, this top-down control may cascade to the phytoplankton level (Carpenter et al. 1987, Pace et al. 1999). The importance of top-down control for structuring the freshwater environment depends on the trophic status and morphology of the lake (Pace et al. 1999, Jeppesen et al. 2003) and is generally higher in shallow lakes (Keller \& Conlon 1994, Jeppesen et al. 1997a). Daphnia spp. is a key grazer in freshwater lakes. It consumes phytoplankton over a broad size spectrum (Gliwicz 1990) and, if abundant, outcompetes small, less efficient grazers such as small-bodied cladocerans, copepods and rotifers (Gilbert 1988). However, due to their large size, Daphnia spp. are highly vulnerable to predation by size-selective planktivorous fish such as perch Perca fluviatilis and roach Rutilus rutilus.

In marine environments, the role of fish is less well studied (Kiørboe 1998), which is surprising because the 
fisheries yield per unit of phytoplankton production is 5 to 10 times higher than in freshwater systems (Rudstam et al. 1994). A few studies have illustrated strong effects of fish on zooplankton dynamics. For example, zooplankton biomass in the subarctic Pacific was high in years with low abundance of pink salmon Oncorhynchus gorboscha, and low in years of high salmon abundance, apparently with cascading effects on phytoplankton (Shiomoto et al. 1997). Likewise, zooplanktivorous herring Clupea harengus and sprat Sprattus sprattus affected the zooplankton community structure in the shallow areas of the Baltic Sea (Hansson et al. 1990, Rudstam et al. 1992). However, evidence of clupeid top-down control in the Baltic Sea is ambiguous, as interannual variability of zooplankton abundance did not relate significantly to fish density at 3 selected stations (Möllmann \& Köster 1999), perhaps because they also included deeper parts of the sea for sampling. Calanoid copepods are the key zooplankton grazers in marine systems (Kiørboe 1998), but in well-mixed shallow estuarine waters, mussels may also be important filter feeders that help maintain low chl a concentrations, even in nutrient-enriched systems (Møhlenberg 1995, Haaner \& Rodhe 2000).

North European brackish lakes with intermediate salinities ( 2 to $8 \mathrm{psu}$ ) differ in structure from freshwater lakes and marine systems. They are often species-poor, and large-bodied mussels are typically absent (Moss 1994). At low salinities, cladocerans may potentially be important grazers (Jeppesen et al. 1994). However, many cladocerans, particularly daphnids, typically disappear at salinities $>3$ to 4 psu (Jeppesen et al. 1994, Moss 1994), and are replaced by rotifers and calanoid copepods such as Eurytemora affinis and Acartia tonsa. Zooplankton grazing on phytoplankton in eutrophic brackish lakes is markedly lower than in comparable freshwater lakes, which has been attributed to higher top-down control by fish and invertebrate predators, including sticklebacks Gasterosteus aculeatus and Pungitius pungitius, and mysids Neomysis integer (Jeppesen et al. 1994, 1997b). Even though the diet of sticklebacks also includes mysids, these 2 species can co-exist, because sticklebacks only consume small specimens of mysids, while the predation pressure on gravid females is low (Søndergaard et al. 2000). Furthermore, as sticklebacks primarily prey on large-bodied zooplankton and mysids on small-bodied zooplankton (Williams \& Delbeek 1989, Pont et al. 1991, Aaser et al. 1995), and as they both have more than 1 cohort per year, the predation pressure on zooplankton remains continuously high in nutrient-rich brackish lakes (Søndergaard et al. 2000).

To elucidate the structuring role of fish in brackish lakes, we conducted a mesocosm experiment in nutrient-enriched enclosures at low salinity (2 psu). We examined changes in zooplankton communities and phytoplankton biomass ( $\mathrm{chl}$ a) at different densities of 3-spined stickleback. Our aims included the identification of a fish density below which zooplankton escape top-down control and generate a clearwater state in brackish lakes with low salinity.

\section{MATERIALS AND METHODS}

Experimental design. The experiment was carried out from 3 May to 27 September 2000, in the slightly brackish (0.5 psu) Lake Kogleakssøen located in the conservation area and bird sanctuary of Vejlerne, Northern Jutland, Denmark. A wooden platform was constructed with additional poles on both sides as attachments to the enclosures. Twelve enclosures with a diameter of $1.2 \mathrm{~m}$ were placed at a depth of 70 to $80 \mathrm{~cm}$. Each enclosure, consisting of a clear polyethylene tube, was kept open to the sediment. The top of the tube was attached to a plastic hoop and the tube was wrapped around a metal cylinder which was forced into the sediment. The plastic hoop was suspended approx. $30 \mathrm{~cm}$ above the water's surface, between 4 wooden poles, using elastic connectors. As the enclosures were filled with water, a net was held underneath them to prevent fish entrance. The net was removed again when the enclosures had reached the sediment. A net to ward off birds was permanently suspended over each enclosure. The salinity was adjusted to $2 \mathrm{psu}$ by adding $6.71 \mathrm{~kg} \mathrm{NaCl}, 2.09 \mathrm{~kg} \mathrm{MgSO}_{4}, 7 \mathrm{H}_{2} \mathrm{O}$ and $9.68 \mathrm{~g} \mathrm{NaHCO}_{3}$ dissolved in $30 \mathrm{l}$ of water from the lake to each enclosure while stirring with a paddle and monitoring the salinity. To allow colonisation of a plankton community adapted to the newly adjusted salinity, the enclosures were inoculated with sediment and water samples from nearby brackish and saline waters on 5 May. On 10 May, nutrients $\left(\mathrm{Ca}\left[\mathrm{NO}_{3}\right]_{2}\right.$, $4 \mathrm{H}_{2} \mathrm{O}$ and $\mathrm{Na}_{2} \mathrm{HPO}_{4}, 7 \mathrm{H}_{2} \mathrm{O}$ ) were added, yielding an initial concentration of $3.5 \mathrm{mg} \mathrm{N}^{-1}$ and $0.4 \mathrm{mg} \mathrm{P} \mathrm{l}^{-1}$. A high nutrient level was chosen to avoid nutrient limitation of phytoplankton growth. Salinity was checked and adjusted on each sampling date. Male 3-spined sticklebacks Gasterosteus aculeatus were caught in nearby brackish (1.6 to 3.5 psu) waters, weighed, measured (average weight $1.7 \mathrm{~g}$, SD 0.3; average length $5.8 \mathrm{~cm}, \mathrm{SD} \mathrm{0.4)}$, and stocked in the enclosures at a density gradient of $0,1,2,4,8$ and 16 sticklebacks per enclosure (referred to as F0 to F16). Experiments were carried out in duplicate, so enclosures of each density were replicated. Salinity was mistakenly raised too high in one of the enclosures with 4 fish, and it was therefore excluded from the analysis.

Sampling and processing. Weekly samplings were conducted from 16 May to 14 June, and then every 
2 wk until 20 September. A tube sampler was used for zooplankton samplings (length $=1.85 \mathrm{~m}$, depth $=7 \mathrm{~cm}$, with a closing device at the bottom). In each enclosure, the sampling was conducted at 5 stations along a transect. The water was mixed in a barrel, and a 2 to 51 subsample filtered onto a $50 \mu \mathrm{m}$ filter. The zooplankton were immediately preserved in Lugol's solution for identification in the laboratory.

Water samples were collected in acid-washed glass bottles for determination of chl $a$ and nutrients. To measure water transparency, we used a Schnell's tube, which consists of a small disc lowered into a metallic tube filled with the water to be analysed. This was used because the Secchi depth occasionally reached the sediment surface. Schnell depth $(x)$ was converted to Secchi depth $(y)$ from the regression obtained in this study: $y=1.64 x+7.9, \mathrm{r}^{2}=0.80, \mathrm{n}=101$. Temperature and salinity were measured after gently stirring water in the enclosures with a paddle. Water depth was measured and macrophytes were continuously removed throughout the experimental period with a hoe (to remove Myriophyllum spicatum L.) or a sieve (to remove Lemna minor L.) to ensure comparable conditions in all enclosures.

Cladocerans and adult copepods were identified to species, and rotifers identified to genus level. Nauplii and copepodites were classified as cyclopoids or calanoids. If subsampling was conducted, it included at least 75 individuals of the most common species or genera (Hansen et al. 1992). Cladoceran length was measured using a digital picture from a stereomicroscope. Twenty-five individuals of each species were measured from the base of the tail spine to the top of the head. Cladoceran biomass was determined using established length/weight relationships (Hansen et al. 1992). Standard values of length and biomass for each copepod species, copepodites and nauplii were taken from Jensen et al. (1996). Rotifer length was measured on 25 individuals and biomass determined using length/weight relationships obtained from Hansen et al. (1992). Chl a was calculated spectrophotometrically following extraction with ethanol (Jespersen \& Christoffersen 1987). For determination of the zooplankton:phytoplankton ratio, chl a was converted to phytoplankton dry weight using a chl a:C ratio of 30 and a dry weight (DW):C ratio of 2.2 (Jeppesen et al. 1994). Total phosphorus (TP) was determined after persulphate digestion (Koroleff 1970) and total nitrogen (TN) after potassium persulphate digestion (Solórzano \& Sharp 1980).
Fish density. If observed, dead fish were replaced at each sampling date. From 5 to 17 July, a markrecapture experiment was conducted according to Mortensen et al. (1990) using Breder traps, gill nets (width = $6.25 \mathrm{~mm}$ ) and a landing net (diameter $=60 \mathrm{~cm}$ ). Despite the replacement of dead fish, stickleback density was reduced in both F16 replicates to approximately 6 fish (Table 1). In the other enclosures, fish mortality was not as high, reaching up to $50 \%$ in an F2 and F4 enclosure (Table 1). Original fish densities were restored in all enclosures by 27 July. On 26 September, the remaining fish were captured by repeated use of the landing net.

Statistical analyses. The effects of fish density on water clarity, chl $a$ and zooplankton biomass and composition were assessed by regression analysis. Percentages were arcsin-transformed and all other values ln-transformed to stabilise variance. Data are integrated from 31 May to 20 September, i.e. the first $2 \mathrm{wk}$ were considered an acclimatisation period and omitted. Because of the changing fish densities through mortality and re-stocking, we used a timeweighted average for the integrated period.

\section{RESULTS}

Average temperature in the enclosures was $15.7^{\circ} \mathrm{C}$ during the study period (highest in mid-June at $23.2^{\circ} \mathrm{C}$, and lowest in late September at $11.1^{\circ} \mathrm{C}$ ). The average depth ranged between 66 and $78 \mathrm{~cm}$, being lowest in late August and highest in late May. Salinity averaged $2.0 \mathrm{psu}$ (SD $0.2 \mathrm{psu}$ ), TP averaged $1.50 \mathrm{mg} \mathrm{l}^{-1}$ (SD $0.59 \mathrm{mg} \mathrm{l}^{-1}$ ) and TN averaged $4.2 \mathrm{mg} \mathrm{l}^{-1}$ (SD $1.6 \mathrm{mg} \mathrm{l}^{-1}$ ).

No significant differences were found in chl a among the enclosures on the first sampling date. A significant positive correlation between fish density and chl a was

Table 1. Gasterosteus aculeatus. Survey of stocked and recaptured stickleback in the different enclosures during the experiment. The calculated timeweighted averages are used in regression analyses. Enclosures F0 to F16 refer to fish densities of 0 to 16, respectively. Experiments were performed in duplicate

\begin{tabular}{|lccccc|}
\hline Enclosure & $\begin{array}{c}\text { Stocked } \\
\text { 7 May }\end{array}$ & $\begin{array}{c}\text { Recaptured } \\
\text { 17 Jul }\end{array}$ & $\begin{array}{c}\text { Restocked } \\
\text { 26 Jul }\end{array}$ & $\begin{array}{c}\text { Recaptured } \\
\text { 26 Sep }\end{array}$ & $\begin{array}{c}\text { Time-weighted } \\
\text { average }\end{array}$ \\
\hline F0 & 0 & 0 & 0 & 0 & 0 \\
& 0 & 0 & 0 & 0 & 0 \\
F1 & 1 & 1 & 1 & 1 & 1 \\
& 1 & 1 & 1 & 1 & 1 \\
F2 & 2 & 1 & 2 & 0 & 1.3 \\
& 2 & 2 & 2 & 0 & 1.6 \\
F4 & 4 & 2 & 4 & 2 & 2.9 \\
F8 & 8 & 8 & 8 & 3 & 6.9 \\
& 8 & 8 & 8 & 6 & 7.6 \\
F16 & 16 & 6 & 16 & 0 & 9.4 \\
& 16 & 6 & 16 & 4 & 10.2 \\
\hline
\end{tabular}




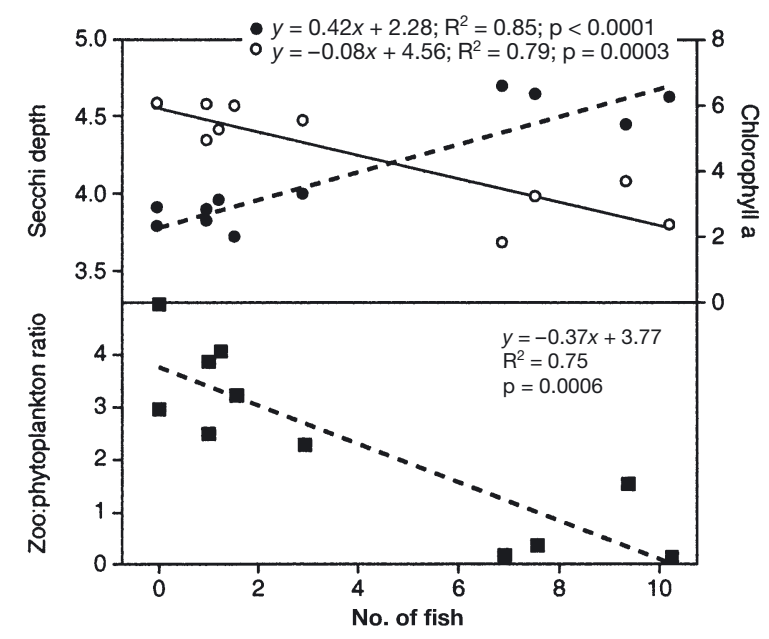

Fig. 1. Regression analysis of $\mu g \operatorname{chl~a~}^{-1}(\bullet)$, Secchi depth in $\mathrm{cm}(\mathrm{O})$ and zooplankton:phytoplankton ratio (squares) subject to different stickleback Gasterosteus aculeatus densities. Dependent variables are $\log _{\mathrm{e}}$-transformed

recorded, whereas Secchi depth decreased with increasing fish density (Fig. 1). The zooplankton: phytoplankton ratio was negatively correlated with fish density.

Total zooplankton biomass was not correlated with fish density (Fig. 2). However, the biomass of largebodied cladocerans was negatively correlated with fish density; small-bodied cladoceran biomass, copepod biomass and rotifer biomass correlated positively with fish density.

The cladoceran community comprised small- (Chydorus sphaericus, mean length $0.3 \mathrm{~mm}$; Ceriodaphnia sp., mean length $0.6 \mathrm{~mm}$ ) and large-bodied cladocerans (Daphnia pulex, D. hyalina, D. galeata, mean length $1.2 \mathrm{~mm}$; D. magna, mean length $1.9 \mathrm{~mm}$; Simocephalus vetulus, mean length $1.5 \mathrm{~mm}$ ). Average cladoceran size decreased significantly with increasing fish density (Fig. 3). The relative contribution of large-bodied species correlated weakly or not at all with fish density. However, the contribution of the small-bodied cladoceran Chydorus sphaericus constituted a larger part of the cladoceran community at higher fish densities, which was a significant positive correlation (Fig. 3).

The large-bodied copepod Megacyclops viridis (mean length of adult females $=1.1 \mathrm{~mm}$ ) correlated negatively with fish density, whereas the small-bodied copepod Mesocyclops leukartii (mean length of adult females $=0.6 \mathrm{~mm}$ ) correlated positively (Fig. 4). However, other copepod species, such as Cyclops vicinus, Eucyclops serrulatus and Eurytemora affinis, showed no correlation with fish density.

The relative distribution of different stages of copepods correlated with fish density. The abundance of advanced stages of copepods and adults had a signifi- cant positive correlation with fish density, whereas nauplii decreased at higher fish densities (Fig. 5). Fish density had no effect on the biomass of adult copepods; biomass of copepodites and nauplii, however, was positively correlated with fish density.

Rotifer species composition failed to show a clear relationship to fish density (Fig. 6), although Polyarthra sp. showed a weak positive correlation to increasing density.

\section{DISCUSSION}

Our results suggest that sticklebacks at high density can exert strong top-down control on zooplankton

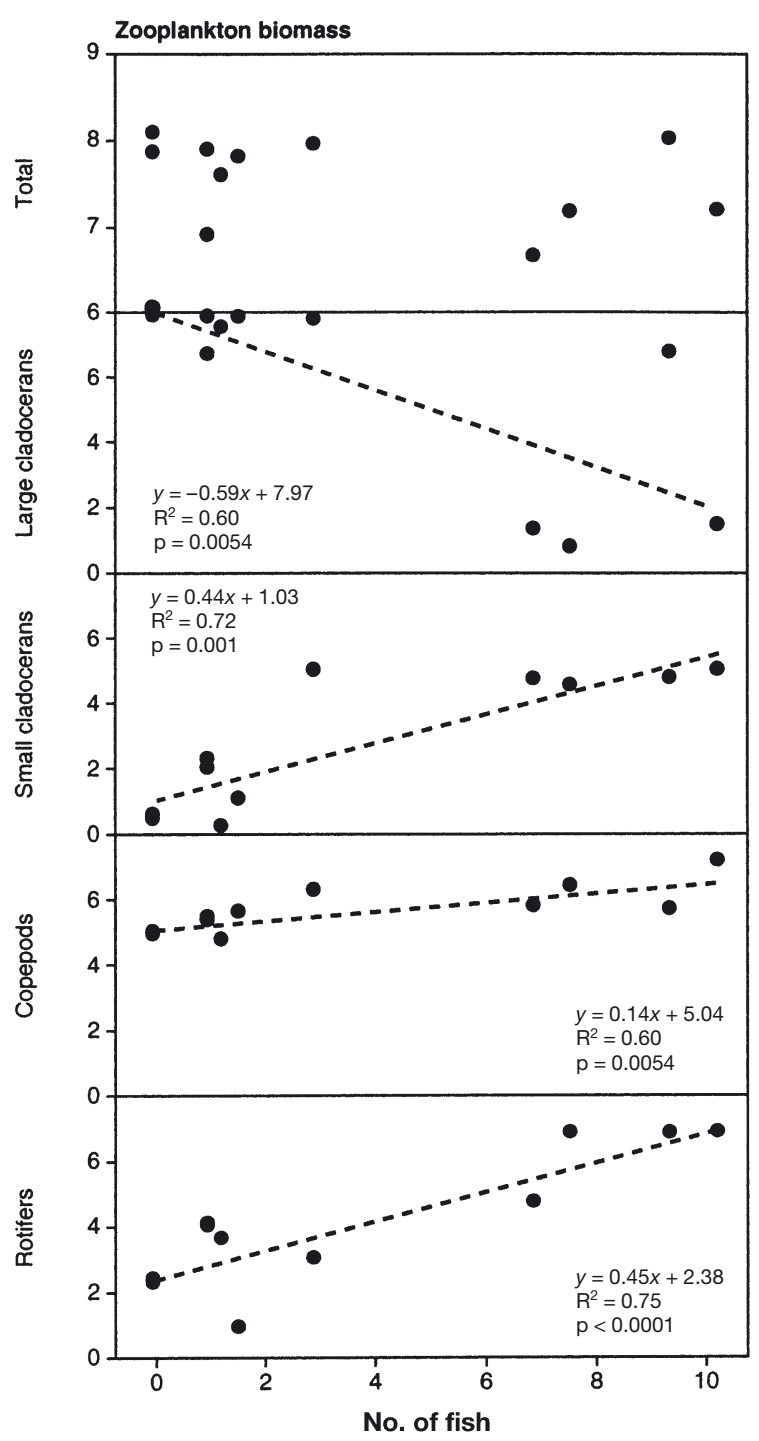

Fig. 2. Regression analysis of total zooplankton biomass, large cladoceran biomass, small cladoceran biomass, copepod biomass and rotifer biomass subject to different stickleback Gasterosteus aculeatus densities. All biomasses are given as $\log _{\mathrm{e}}$-transformed $\mu \mathrm{g} \mathrm{l}^{-1}$ 


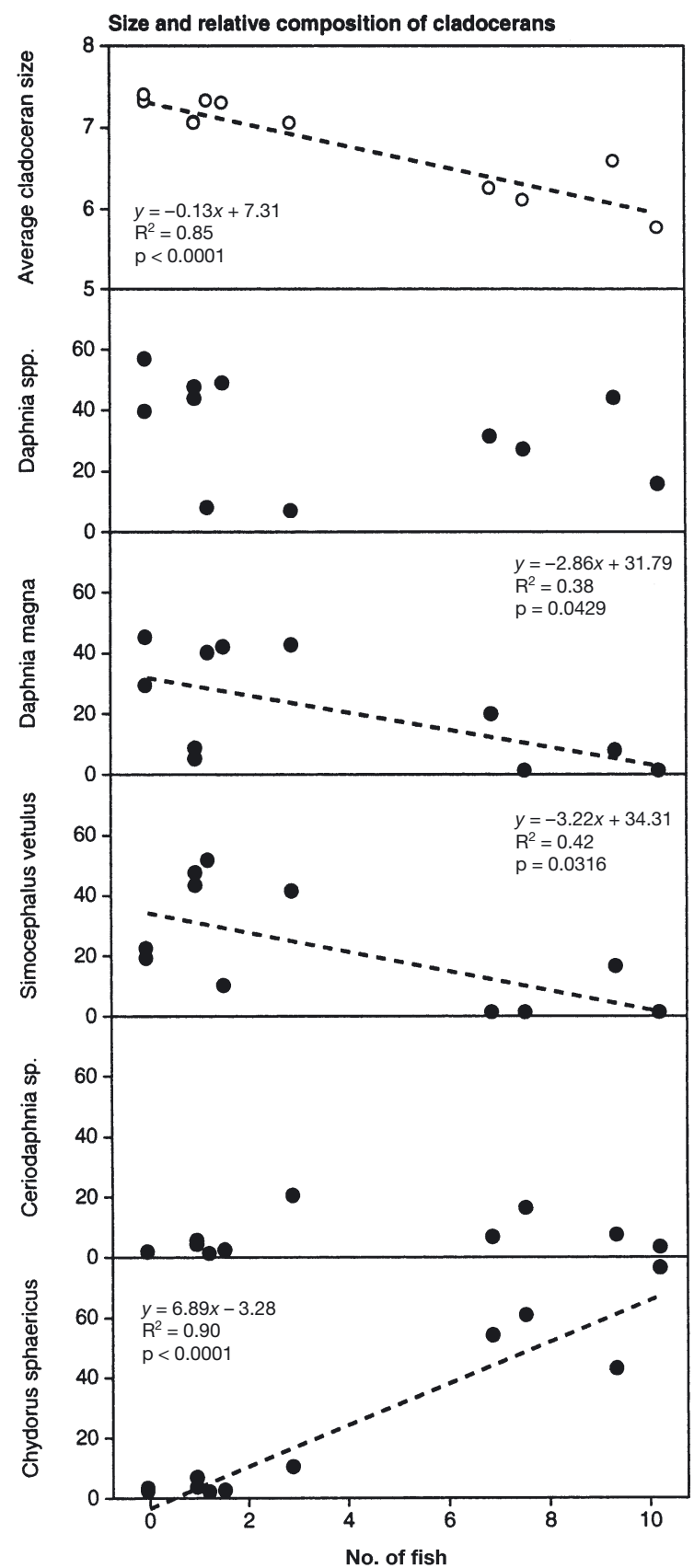

Fig. 3. Regression analysis of cladoceran size and relative distribution of Daphnia spp., D. magna, Simocephalus vetulus, Ceriodaphnia sp. and C. sphaericus subject to different stickleback Gasterosteus aculeatus densities. Cladoceran size data are given as $\log _{\mathrm{e}}$-transformed $\mu \mathrm{m}$ and relative distribution data are arcsin-transformed percentages

community structure and cause a cascading effect on phytoplankton biomass. At fish densities below $4 \mathrm{~m}^{-2}$, large-bodied cladocerans and copepods dominated the zooplankton community. Rotifer biomass was depressed, as is also seen in freshwater lakes (Gilbert \& Stemberger 1985, Lampert \& Rothhaupt 1991), most

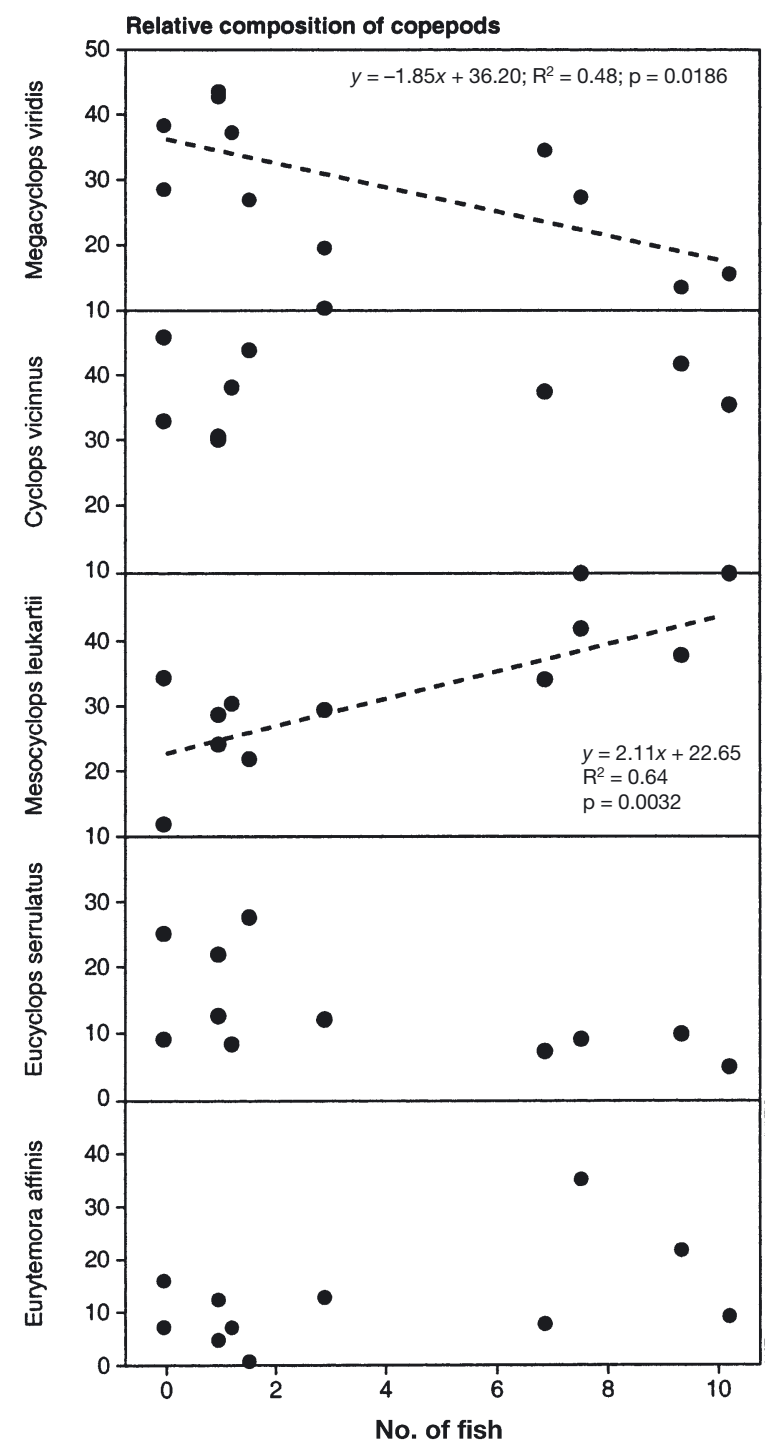

Fig. 4. Regression analysis of relative distribution of Megacyclops, Cyclops vicinus, Mesocyclops leukartii, Eucyclops serrulatus and Eurytemora affinis subject to different stickleback Gasterosteus aculeatus densities. Dependent variables are arcsin-transformed percentages

likely reflecting exploitative competition by Daphnia spp. (May \& Jones 1989) and mechanical (Gilbert 1988) and chemical interference (Conde-Porcuna 1998). In addition, the zooplankton:phytoplankton ratio exceeded 1, which is indicative of a high grazing pressure on phytoplankton (Jeppesen et al. 2002) and, accordingly, chl a was low $\left(<20 \mu \mathrm{g} \mathrm{l}^{-1}\right)$ despite high nutrient concentrations.

A marked shift to a turbid state with high chl $a$ and low Secchi depth occurred at higher fish densities (>6 ind. $\mathrm{m}^{-2}$ ). Large-bodied cladocerans, which are highly vulnerable to stickleback predation (Pont et al. 1991, Stephen et al. 1998), almost disappeared. Small- 


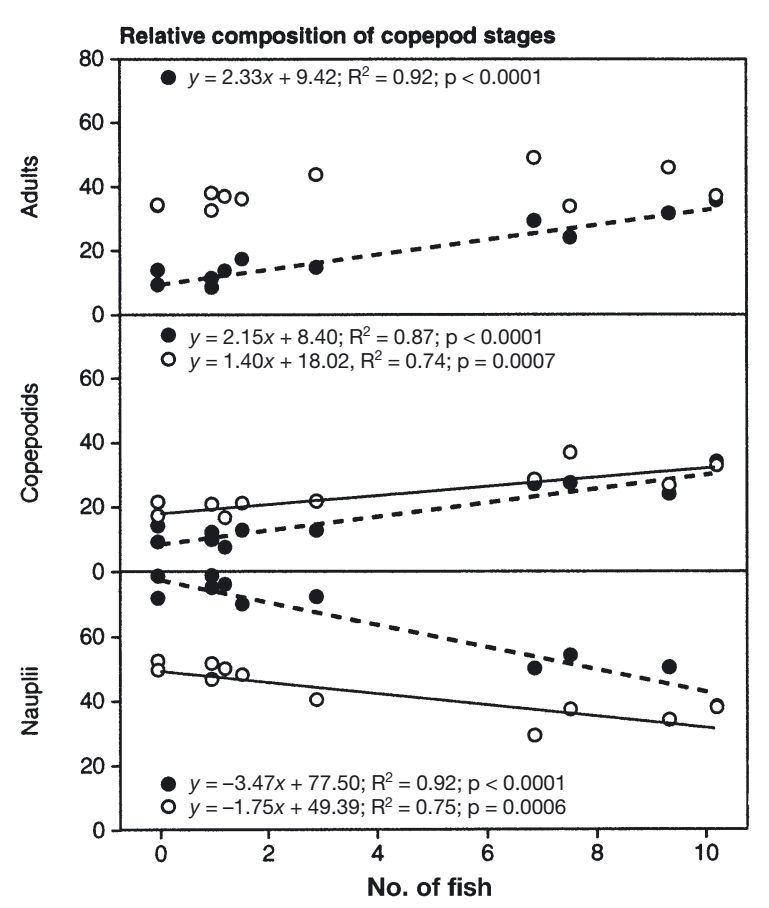

Fig. 5. Regression analysis of relative distribution of different stages of copepods subject to different stickleback Gasterosteus aculeatus densities, based on abundance $(\bullet)$ and biomass (०). Dependent variables are arcsin-transformed percentages

bodied cladocerans increased in abundance, but it was the rotifers and cyclopoid copepods that dominated the zooplankton community. Although data were insufficient to distinguish between linear and threshold effects of fish density, due to low replication and the absence of intermediate fish densities, a shift from a clear to a turbid state occurred at 4 to 6 sticklebacks $\mathrm{m}^{-2}$.

Major changes also occurred at species and genus level. Large-bodied cladocerans such as Daphnia magna, D. pulex, D. hyalina, D. galeata, and Simocephalus vetulus dominated the cladoceran community at low fish density. At intermediate fish density, the smaller Ceriodaphnia sp. contributed substantially to the biomass, while $C$. sphaericus dominated at high fish density. A similar cladoceran community structure and response to increasing stickleback abundance occurred in oligohaline marshes and pools in the Camargue (southern France) (Pont et al. 1991). D. magna, S. vetulus and Ceriodaphnia sp. are among the few commonly found species or genera in subsaline and hyposaline (classification by Hammer 1986) waters on most continents (Frey 1993, Timms 1993, Boronat et al. 2001); they all belong to the group of hyperosmotic regulators at low salinities (Aladin \& Potts 1995). Bosmina spp., which often dominates the pelagial cladoceran community in freshwater lakes exhibit- ing high fish-predation pressure, was not important in the enclosures with intermediate to high fish densities, most likely due to higher sensitivity to saline conditions (Jeppesen et al. 1994), although B. longirostris occurs at salinities as high as 6 psu in the Baltic Sea (Hofmann 1987). Instead, the cosmopolitan species $C$. sphaericus, which is well adapted to brackish water (Frey 1993, Timms 1993, Amsinck et al. unpubl.), becomes dominant. In the Baltic Sea, this species occurs at salinities at high as 10.5 (Hofmann 1987), and 8 to 10 in several other studies of thalassic saline water bodies (Aladin \& Potts 1995).

The copepod community also seemed to be affected by size-selective predation by sticklebacks. The largebodied Megacyclops viridis was more abundant at lowthan at high fish densities, while Mesocyclops leukartii increased with fish density. Eurytemora affinis occasionally occurred at high fish densities. However, $C y-$ clops vicinus seemed unaffected by fish presence and constituted a substantial part of the copepod community along the fish gradient. It may seem surprising that the small stages of copepod nauplii dominated at low fish-predation levels, while the much larger, advanced stages dominated at higher levels. This may reflect the fact that large-bodied cladocerans dominating at low fish densities are powerful competitors with the advanced copepod stages, both directly for the same food resources, but also indirectly because the large-bodied cladocerans depress the prey (rotifers, ciliates) of the potentially predatory-advanced cyclopoid stages. By contrast, the much higher food abundance at high fish densities favours the advanced stages of cyclopoids, which in turn may negatively affect the nauplii through

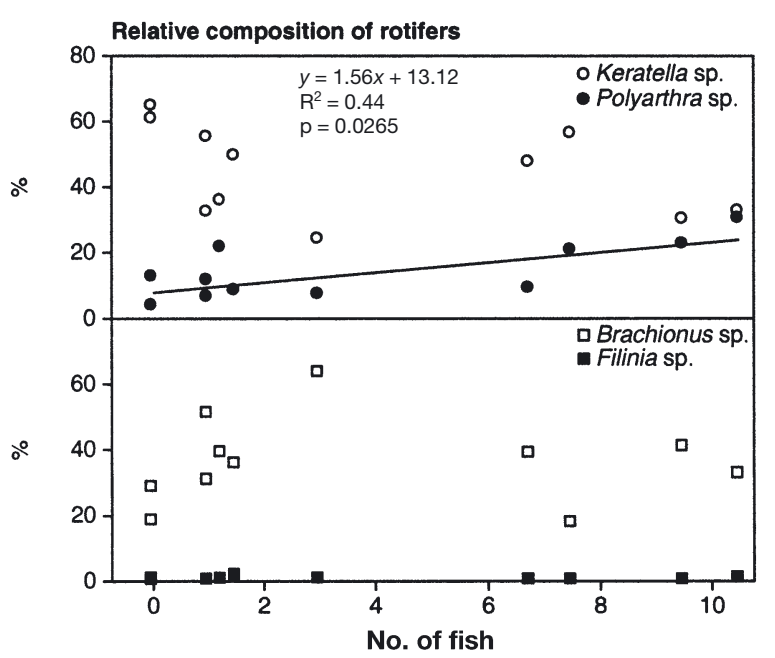

Fig. 6. Regression analysis of relative distribution of Keratella sp., Brachionus sp., Polyarthra sp. and Filinia sp. subject to different stickleback Gasterosteus aculeatus densities.

Dependent variables are arcsin-transformed percentages 
cannibalism. E. affinis, which usually dominates the copepod community in North European brackish lakes at salinities of 1 to 8 psu (Heerkloss et al. 1991, Jeppesen et al. 1994, Moss 1994), only occasionally became abundant, and even then only in a few enclosures, despite it being added to all enclosures at the onset of the experiment. While a clear, and most likely indirect, effect of fish density on the abundance of rotifers occurred, the relative abundance of the different species showed no clear trend along the fish density gradient. During most of the summer, Keratella spp. and Brachionus spp., which are typically most frequently abundant under sub-haline conditions (Heerkloss et al. 1991), dominated the rotifer community.

Shifts in the zooplankton community structure at threshold fish densities have occurred in several freshwater lakes. For example, when $0^{+}$yellow perch Perca fluviatilis exceeded 1.4 ind. $\mathrm{m}^{-2}$, the Daphnia pulex population collapsed in Lake Oneida (Mills et al. 1987). Similarly, zooplankton abundance was severely reduced in a set of enclosures above a critical fish biomass of $5 \mathrm{~g} \mathrm{~m}^{-2}$ (McQueen \& Post 1988). However, the fish threshold-density or -biomass is by no means fixed, but varies with trophic state and, thus, with the abundance of food available to predatory zooplankton (Jeppesen et al. 2003). It is difficult to apply findings from enclosure studies to whole-lake ecosystems, because interactions may be stronger in enclosures due to the lack of escape opportunities for prey zooplankton. This may be counterbalanced by increased zooplankton survival due to access to alternative food sources, including periphytes, detritus and bacteria growing on the enclosure walls. The sustained high zooplankton:phytoplankton ratio in low-fish density enclosures supports this view. However, in coastal brackish lakes, zooplankton also often have access to numerous periphyton-covered surfaces and to sediment epipelon, and the shallow depth of the lakes leads to abundant submerged plants, even when the lakes are in a turbid state (in contrast to freshwater lakes) (Jeppesen et al. 1997b). Sticklebacks are usually abundant in north European brackish lakes (Pont et al. 1993, Jeppesen et al. 1994, Moss 1994). Natural densities of sticklebacks in tidal salt-marsh pools can be as high as 35 (Castonguay \& FitzGerald 1990) and 20 sticklebacks $\mathrm{m}^{-2}$ (Worgan \& FitzGerald 1981), whereas Williams \& Delbeek (1989) found 25 sticklebacks $\mathrm{m}^{-2}$ in an estuary. Therefore, our density of 4 to 6 sticklebacks $\mathrm{m}^{-2}$ which leads to the shift to a turbid state is surpassed in many brackish lakes and lagoons. This allows us to conclude that sticklebacks may be an important contribution to the typically low zooplankton:phytoplankton ratio found in eutrophic brackish lakes (Jeppesen et al. 1994). Our results provide experimental support for the empirically based conclusion of high predator control of zooplankton and the consequently high phytoplankton biomass in such environments (Jeppesen et al. 1994, 1997b). However, our results also show that when salinity is low, Daphnia spp. will be abundant, and a clearwater state is likely to occur (even at high nutrient concentrations) when fish density declines below a certain level (4 to 6 sticklebacks $\mathrm{m}^{-2}$ in our study).

Acknowledgements. We thank L. Skov Hansen, L. Nørgaard and K. Thomsen for nutrient analyses, and the rest of the staff at the National Environmental Research Institute, Silkeborg, for technical assistance. We are grateful to K. Richardson for valuable comments on an earlier version of the manuscript. Furthermore, we wish to thank R. L. Burks, Thomas Davidson, L. Schreiber and A. M. Poulsen for editorial assistance.

\section{LITERATURE CITED}

Aaser HF, Jeppesen E, Søndergaard M (1995) Seasonal dynamics of the mysid Neomysis integer and its predation on the copepod Eurytemora affinis in a shallow hypertrophic brackish lake. Mar Ecol Prog Ser 127:47-56

Aladin NV, Potts WTW (1995) Osmoregulatory capacity of Cladocera. J Comp Physiol B 164:671-683

Boronat L, Miracle ML, Armengol X (2001) Cladoceran assemblages in a mineralization gradient. Hydrobiologia 442: 75-88

Brooks JL, Dodson SI (1965) Predation, body size, and composition of plankton. Science 150:28-35

Carpenter SR, Kitchell JF, Hodgson JR, Cochran PA and 6 others (1987) Regulation of lake primary productivity by food web structure. Ecology 68:1863-1876

Castonguay M, FitzGerald GJ (1990) The ecology of the calanoid copepod Eurytemora affinis in salt marsh tide pools. Hydrobiologia 202:125-133

Conde-Porcuna J (1998) Chemical interference by Daphnia on Keratella: a life table experiment. J Plankton Res 20: $1637-1644$

Frey DG (1993) The penetration of cladocerans into saline waters. Hydrobiologia 267:233-248

Gilbert JJ (1988) Suppression of rotifer populations by Daphnia: a review of the evidence, the mechanisms, and the effects on zooplankton community structure. Limnol Oceanogr 33:1286-1303

Gilbert JJ, Stemberger RS (1985) Control of Keratella populations by interference competition from Daphnia. Limnol Oceanogr 330:180-188

Gliwicz ZM (1990) Why do cladocerans fail to control algal blooms? Hydrobiologia 200/201:83-97

Haaner J, Rodhe J (2000) Mussel Mytilus edulis (L.) filtering of Baltic Sea outflow through the Oresund-an example of a natural large-scale ecosystem restoration. J Shellfish Res 19:413-441

Hammer UT (1986) Saline lake ecosystems of the world. Dr W. Junk Publishers, Dordrecht

Hansen AM, Jeppesen E, Bosselman S, Andersen P (1992) Zooplankton i søer-metoder og artslister. Miljøprojekt 205, Miljøministeriet, Copenhagen

Hansson S, Larsson U, Johansson S (1990) Selective predation by herring and mysids, and zooplankton community 
structure in a Baltic Sea coastal area. J Plankton Res 12: 1099-1116

Heerkloss R, Schnese W, Adamkiewicz-Chojnacka B (1991) Seasonal variation in the biomass of zooplankton in two shallow coastal water inlets differing in their stage of eutrophication. Int Rev Gesamten Hydrobiol 76:397-404

Hofmann W (1987) Stratigraphy of Cladocera (Crustacea) and Chironomidae (Insecta:Diptera) in three sediment cores from the Central Baltic Sea as related to paleo-salinity. Int Revue Gesamten Hydrobiol 72:97-106

Hrbácek J, Dvorakova M, Korinek V, Procházkóva L (1961) Demonstration of the effect of the fish stock on the species composition of zooplankton and the intensity of metabolism of the whole plankton association. Verh Int Ver Limnol 14:192-195

Jensen JP, Jeppesen E, Søndergaard M, Jensen K (1996) Interkalibrering af dyreplanktonundersøgelser i søer. DMU, Miljøministeriet, Silkeborg

Jeppesen E, Søndergaard M, Kanstrup E, Petersen B and 5 others (1994) Does the impact of nutrients on the biological structure and function of brackish and freshwater lakes differ? Hydrobiologia 275/276:15-30

Jeppesen E, Jensen JP, Søndergaard M, Lauridsen TL, Pedersen LJ, Jensen L (1997a) Top-down control in freshwater lakes: the role of nutrient state, submerged macrophytes and water depth. Hydrobiologia 342/343:151-164

Jeppesen E, Søndergaard M, Jensen JP, Kanstrup E, Petersen B (1997b) Macrophytes and turbidity in brackish lakes with special emphasis on top-down control. In: Jeppesen E, Søndergaard Ma, Søndergaard Mo, Christoffersen K (eds) The structuring role of submerged macrophytes in lakes. Ecological Studies 13. Springer-Verlag, Berlin, p 369-377

Jeppesen E, Søndergaard Ma, Søndergaard Mo, Christoffersen K, Theil-Nielsen J, Jürgens K (2002) Cascading trophic interactions in the littoral zone: an enclosure experiment in shallow Lake Stigsholm, Denmark. Arch Hydrobiol 153:533-555

Jeppesen E, Jensen JP, Jensen C, Faafeng B and 5 others (2003) The impact of nutrient state and lake depth on top-down control in lakes: study of 466 lakes from the temperate zone to the Arctic. Ecosystems 6:313-325

Jespersen AM, Christoffersen K (1987) Measurements of chlorophyll a from phytoplankton using ethanol as extraction solvent. Arch Hydrobiol 109:445-454

Keller W, Conlon M (1994) Crustacean zooplankton communities and lake morphometry in precambrian shield lakes. Can J Fish Aquat Sci 51:2424-2434

Kiørboe T (1998) Population regulation and the role of mesozooplankton in shaping marine pelagic food webs. Hydrobiologia 363:13-27

Koroleff F (1970) Determination of total phosphorus in natural water by means of persulphate oxidation. Interlaboratory Rep No. 3. Cons Int Explor Mer, Copenhagen

Lampert W, Rothhaupt KO (1991) Alternating dynamics of rotifers and Daphnia magna in a shallow lake. Arch Hydrobiol 120:447-456

May L, Jones DH (1989) Does interference competition from

Editorial responsibility: Otto Kinne (Editor),

Oldendorf/Luhe, Germany
Daphnia affect populations of Keratella cochlearis in Loch Leven, Scotland? J Plankton Res 11:445-461

McQueen DJ, Post JR (1988) Cascading trophic interactions uncoupling at the zooplankton-phytoplankton link. Hydrobiologia 159:277-296

Mills EL, Forney JL, Wagner KJ (1987) Fish predation and its cascading effect on the Oneida Lake food chain. In: Kerfoot WC, Sih A (eds) Predation: direct and indirect impacts on aquatic communities. University Press of New England, Hanover, NH, p 118-131

Mortensen E, Jensen HJ, Müller JP, Timmermann M (1990) Fiskeundersøgelser i søer - undersøgelsesprogram, fiskeredskaber og metoder. Teknisk anvisning fra DMU nr. 3, Miljøministeriet, Copenhagen

Moss B (1994) Brackish and freshwater shallow lakesdifferent systems or variations on the same theme? Hydrobiologia 275/276:1-14

Møhlenberg F (1995) Regulation mechanisms of phytoplankton growth and biomass in a shallow estuary. Ophelia 42: $239-256$

Möllmann C, Köster FW (1999) Food consumption by clupeids in the Central Baltic: evidence for top-down control? ICES J Mar Sci 56:100-113

Pace M, Cole JJ, Carpenter SR, Kitchell JF (1999) Trophic cascades revealed in diverse ecosystems. Trends Ecol Evol 14:483-488

Pont D, Crivelli AJ, Guillot F (1991) The impact of threespined sticklebacks on the zooplankton of a previously fish-free pool. Freshw Biol 26:149-163

Rudstam LG, Hansson S, Johansson S, Larsson U (1992) Dynamics of planktivory in a coastal area of the northern Baltic Sea. Mar Ecol Prog Ser 80:159-173

Rudstam LG, Aneer G, Hildén M (1994) Top-down control in the pelagic Baltic ecosystem. Dana 10:105-129

Shiomoto A, Tadokoro K, Nagasawa K, Ishida Y (1997) Trophic relations in the subarctic North Pacific ecosystem: possible feeding effect from pink salmon. Mar Ecol Prog Ser 150:75-85

Solórzano L, Sharp JH (1980) Determination of total dissolved nitrogen in natural waters. Limnol Oceanogr 25: 751-754

Stephen D, Moss B, Phillips G (1998) The relative importance of top-down and bottom-up control of phytoplankton in a shallow macrophyte dominated lake. Freshw Biol 39: 699-713

Søndergaard M, Jeppesen E, Aaser HF (2000) Neomysis integer in a shallow hypertrophic brackish lake: distribution and predation by three-spined stickleback (Gasterosteus aculeatus). Hydrobiologia 428:151-159

Timms BV (1993) Saline lakes of the Paroo, inland New South Wales, Australia. Hydrobiologia 267:269-289

Williams DD, Delbeek JC (1989) Biology of the three-spined stickleback, Gasterosteus aculeatus, and the blackspotted stickleback, G. wheatlandi, during their marine pelagic phase in the Bay of Fundy, Canada. Env Biol Fish 24:33-41

Worgan JP, FitzGerald GJ (1981) Diel activity and diet of three sympatric sticklebacks in tidal salt marsh pools. Can J Zool 59:2375-2379

Submitted: February 20, 2003; Accepted: July 29, 2003

Proofs received from author(s): October 31, 2003 